\title{
191. Podiceps minor.
}

Podiceps minor (Linn.), Finsch \& Hartl. Vög. Ostafr. p. 811; Fischer, J. f. O. 1880, p. 188.

Colymbus minor, Fischer \& Reichenow, J. f. O. 1878, p. 247; Fischer, J.f. O. 1879, p. 297.

Pangani.

This species is to be found throughout the whole of the Ethiopian Region.

\section{Thalacrocorax africanus.}

Graculus africanus (Gm.), Finsch \& Hartl. Vög. Ostafr. p. 847; Fischer \& Reichenow, J. f. O. 1878, p. 247; Fischer, tom. cit. p. 295.

Usambara hills.

The range of this species is probably the entire Ethiopian Region south of $30^{\circ} \mathrm{N}$. lat.; for it is not uncommon on Lake Fayoom near Cairo; but its northern limits on the west coast are not yet so well defined.

7. On a Collection of Lepidoptera from Western India, Beloochistan, and Afghanistan. By Arthur G. Butler, F.L.S., F.Z.S., \&c. Assistant Keeper, Zoological Department, British Museum.

[Received March 28, 1881.]

The collection, of which the following is an account, was received last year, in two consignments, from Major Charles Swinhoe. The first of these was accompanied by a letter dated from Kurrachee 1st May, 1880, in which Major Swinhoe says :- "I send you by this mail another small collection of Lepidoptera in three small boxes. . . . . . I I am afraid there is not much in it you will care for. I have several boxes full of Butterflies and Moths in paper envelopes, but cannot find time to sort them. Mr. Murray, the Curator of the Kurrachee Museum, has gone to Kandahar at his and my expense; and when happier times come I will send you his Afghan collections. One small box I have looked into is very much like a collection from England would be, or rather, I should say, from Europe; it contained Pieris rapa, P. mesentina, Colias chrysotheme ${ }^{1}$, Pieris daplidice, Lyccena cyllarus, one pair of Nymphalidæ I don't know, Deiopeia pulchella, and Grammodes stolida: I hope the others will show a greater variety. Mr. Murray's tour will extend over three months; and therefore his notes and his collection should be valuable; but I am afraid that he will not be able to get beyond Khelat i Gilgai.

"I send you a few notes made during the past year of what my

${ }^{1}$ By this is intended $C$. erate; some of the others, as $L$. cyllarus, are doubtless identified from memory. 
collector has brought in from captures at this place (Kurrachee); it is of course only a very slight sketch. The life of a Chief Commissariat Officer at the base of war operations has not much leisure in it. I have had to keep the army of Southern Afghanistan supplied with pretty well every thing. . . . . It has therefore only been at odd hours, when every one else was sleeping, that I have been able to take occasional notes."

The second consignment consisted of a single small box forwarded on the 12th August, and followed by a letter dated from Quetta 3rd September, 1880, in which Major Swinhoe says:- "I rode up the Bolan 100 odd miles in five days. The heat at Sibi and at the first two stages was intense; but we began to ascend rapidly before reaching Mach, when we got out of the heat, and at Dusht, 6000 feet above sea-level, it was dreadfully cold at night, to me especially, just coming out of the intense heat of the Sind post. You descend again a thousand feet on reaching Quetta.

"I have, as usual, been collecting everywhere. I have my collector with me, who hunts every day; and after my day's work is done I sort the good out of the rubbish, and put them carefully away with the dates attached to the examples; and my friends returning sick or on duty to Kurrachee take them to my wife there, who knows how to take care of them until my return. I hope I shall have a nice report to make to the. British Museum when I return, and send you a fine collection of examples; but indeed both in Birds and Butterflies there is not much new ; most are European species" 1 .

The following is a list of the species :-

\section{RHOPALOCERA。}

\section{NyMPHALIDE.}

\section{Eupleina.}

\section{Euplea vermiculata (No. 1).}

Euplaea vermiculata, Butler, P.Z. S. 1866, p. 276.

Mussoorie (one specimen).

Major Swinhoe says that the allied $\boldsymbol{E}$. core is " taken at Hydrabad, Sind; said to be occasionally taken at Kurrachee-not found here by me:" he also applies the same observation to Danais limniace $^{2}$ and Melanitis ismene.

\section{Parantica nilgiriensis (No. 2).}

Danais nilgiriensis, Moore, Ann. \& Mag. Nat. Hist. ser. 4, vol. xx. p. 44 (1877).

One female specimen. Neilgherries.

3. Parantica aglea (No. 3).

Papilio aglea, Cramer, Pap. Exot. iv. pl. 377. f. E (1782).

One male from Belgaum.

1 My report on Captain Roberts's collection has shown that the Lepidoptera are rather Persian than European species, although allied to European forms.

2 Tirumala limniace, Moore. 


\section{NyMPHALINE.}

\section{Hypolimnas misippus.}

Papilio misippus, Linnæus, Mus. Lud. Ulr. p. 291 (1764).

ot Kurrachee (October, 1879); 우 Kurrachee (July, 1880); 우 Magar Pir, Sind. The feniales are both referable to the variety H. dorippus of Klug. Major Swinhoe remarks of this species :"Common in September; many of the females show great variety in markings, some having the apical area very slightly marked with the usual black markings ; common also in Hydrabad."

H. bolina, L., is stated to be in the Kurrachee Museum, as taken there.

Of the Vanessa (which are not represented in the collection) Major Swinhoe forwards the following notes :-

"Pyrameis cardui, L., January, February, July, August, and December.

"Junonia lemonias, L., in Kurrachee Museum as taken here; $J$. anone, L., January to May, November and December, common; $J$. orithyia, L., April and May, not common; J. asteria, L., Hydrabad, Sind, one specimen taken at Kurrachee in N.W.; J. almana, L., January and November, not common."

\section{Moduza procris (No. 1).}

Limenitis procris, Cramer, Pap. Exot. ii. pl. 106. f. E, F (1779). One example, but only labelled " N. India."

6. Rahinda hordonia (No. 6).

Papilio hordonia, Stoll, Suppl. Cramer, pl. 33. f. 4, 4d (1790).

One example, Neilgherries.

7. Parthenos virens (No. 1$)^{1}$.

Parthenos virens, Moore, Ann. \& Mag. Nat. Hist. ser. 4, vol. xx. p. 47 (1877).

Two specimens, Neilgherries.

8. Cirrochroa swinhoei, sp. n. (No. 3 ).

ㅇ. Allied to C. thais of Ceylon, but of a clear bright fulvous colour above, almost as bright as in $C$. aoris and $C$. mithila, the primaries more falcate than in $C$. thais, the inner or discal zigzag line less strongly defined and more completely separated into <-shaped markings, the very irregular series just beyond the cell considerably more slender, secondaries with all the markings less pronounced: body considerably paler, the thorax pale greenish. Under surface stone-colour, with greenish and flesh-coloured tints, the basal area to the middle being flesh-coloured, the discal lines and outer borders washed with pale olivaceous; the band across the centre rather paler than the ground-colour, but not white or silvery in the type specimen; a diffused double pearly white spot at apex of primaries ; 
pectus whitish, legs flesh-coloured. Expanse of wings 2 inches 7 lines.

One specimen. Neilgherries. Mr. Moore has examples, apparently referable to this species, in his collection from the Neilgherries.

9. Messaras erymanthis (No. 2).

Papilio erymanthis, Drury, Ill. Exot. Ent. i. pl. 15. figs. 3, 4 (1773).

One specimen. Neilgherries.

10. Hypanis polinice (No. 5).

Papilio polinice, Cramer, Pap. Exot. iv. pl. 375. f. G, H (1782)

One specimen. Neilgherries.

11. Melitea robertsil (No. 7).

Melitaa robertsii, Butler, P. Z. S. 1880, p. 406, pl. 39. fig. 2 .

One specimen. Chaman, South Afghanistan, May 1880.

MORPHINE.

12. Discophora tullia (No. 4).

Papilio tullia, Cramer, Pap. Exot. i. pl. 81. f. A, B (1779).

One female specimen. " North India."

\section{LYCANIDE.}

13. Curetis phedrús (No. 2).

Papilio phadrus, Fabricius, Sp. Ins. ii. p. 125 (1781).

One female. Neilgherries.

14. Polyommatus beticus.

Papilio baticus, Linnæus, Syst. Nat. i. (2) p. 789 (1766).

Seven specimens. Kurrachee, May and June, 1879.

Major Swinhoe says that this species is very common in January, April, May, and July.

\section{Catochrysops cnejus.}

Hesperia cnejus, Fabricius, Ent. Syst. Suppl. p. 430 (1798).

Two males. Kurrachee, October 1879.

With this species were two smaller Lycana which agree fairly well with $C$. contracta, and must I think be slight variations of that species; but Major Swinhoe seems to regard them as a seasonal variety of $L$. cnejus. He says :- "The September brood taken here, at the Hubb river, and in the Mulleer, all within a radius of 20 miles from Kurrachee, is more than double the size of those taken in the spring and summer-the former having an expanse of $1 \frac{1}{4}$ inch, while the others are barely 10 lines, the difference every way in size being quite remarkable, whereas in every other respect the examples are identical.'

Of the four specimens now sent as $C$. cnejus, two are typical and 
belong to the large type taken in September; the two others are very like $L$. contracta, are altogether bluer above than $L$. cnejus, and have the discal row of white-zoned black spots on the primaries below interrupted.

\section{Catochrysops contracta?}

Lampides contracta, Butler, P. Z. S. 1880, p. 406, pl. 39. fig. 3. Two specimens (as $L$. cnejus). Kurrachee, June 1879.

17. Catochrysops ella, sp. n. (No. 6).

Allied to C. cnejus, but with the coloration of the wings below more like $C$. pandava. Wings above lilac, greenish at the base, the male with a broad dark brown border twice as wide at apex as towards the external angle; the female with a blackish marginal line and indistinct ocelloid submarginal spots : secondaries with a black marginal line and a submarginal series of six ocelloid spots, less distinct in the male than in the female, the first indistinct in both sexes, the three following brown with white borders, the fifth large, black, with the border white externally and orange internally, anal spot bifid, black with white border; fringe white, tail black tipped with white. Wings below brownish grey, with the spots arranged as in $C$. cnejus, but broader, less prominent; the submarginal spots relieved internally by a rather broad brown border, beyond which is a diffused discal white streak or band; the black ocelli towards the anal angle vary in intensity, and sometimes are almost wholly lost, as in the male before me. Expanse of wings, of 10 lines, of 1 inch.

A pair, rather worn. Kurrachee. ơ, December 1879; 우, January 1880.

There are specimens of this species in $\mathrm{Mr}$. Moore's collection. Major Swinhoe says that it is not common.

18. Lampides elianus (No. 7).

Hesperia alianus, Fabricius, Ent. Syst. iii. 1, p. 280 (1793).

One male. Neilgherries.

19. Tarucus plinius (No. 1).

Hesperia plinius, Fabricius, Ent. Syst. iii. 1, p. 284 (1793).

Two examples. Kurrachee, May and June, 1879. Also occurs in July, and is common.

20. Tarucus nara.

Lyccena nara, Kollar, Hügel's Kaschmir, iv. 2, p. 421 (1848).

Four specimens. Kurrachee, May and October, 1879.

T. nara is said to be common from April to August, and in November.

21. Lycana fugitiva, n. sp.

Intermediate in character between $\boldsymbol{L}$. persica and zephyrus, but nearer to the latter. Wings of the male above bright lilacine blue, 
with a black marginal line, fringe with the basal half grey, the external half white; of the female smoky brown, more or less washed with blue towards the base, a submarginal series of small lunate orange spots, outer border broadly blackish, fringe as in the male. Wings below whity-brown, greyer and paler in the male than in the female; the black spots arranged exactly as in L. zephyrus, but all smaller and with less conspicuously white zones; the double series of submarginal spots on the primaries grey and without connecting orange spots in the male, paler in the female; submarginal spots on the secondaries less distinctly black, the orange spots paler, not relieved by a pure white border as in $L$. zephyrus; base of the secondaries rather more broadly washed with bluish green. Expanse of wings 1 inch $1 \frac{1}{2}$ line.

Three pairs, the females much worn. Quetta, North Beloochistan, March and April.

This is incorrectly labelled L. cyllarus?; the latter is a much larger and very distinct species.

22. Zizera karsandra (Nos. 4 \& 5).

Polyommatus karsandra, Moore, P. Z. S. 1865, p. 505. n. 106, pl. 31. fig. 7 .

Sixteen specimens, but mostly worn or broken. "April, May, July ; very common. Kurrachee."'

23. Scolitantides nyseus (No. 8).

Polyommatus nyseus, Guérin in Deless. Souv. Voy. Ind. p. 78, pl. 22. fig. 1 (1843).

One fair specimen, Hydrabad, Sinde; and one broken, Neilgherries.

\section{Aphneus acamas.}

Lycana acamas, Klug, Symb. Phys. pl. 40. figs. 7-9 (1834).

A pair in good condition. Kurrachee, February and August, 1880. Occurs at "Hydrabad, Sind, in February, March, and August, but is not common."

25. Aphnaus vulcanus, var. (No. 2).

Papilio vulcanus, Fabricius, Syst. Ent. p. 519 (1775).

One worn female. Neilgherries.

Papilionide.

\section{Pierine.}

26. Colias nilgiriensis.

Colias nilagiriensis, Felder, Wien, ent. Mon, iii. p. 395 (1859). Two pairs. Neilgherries.

27. Colias erate.

Papilio erate, Esper, Eur. Schmett. i. (2) pl. 119. fig. 3 (1806).

One worn pair. Quetta, 26th March and 20th April, 1880. 
These specimens are rather smaller than European examples, and may possibly represent a dwarfed race of the species.

\section{Terias hecabeoides.}

Terias hecabeoides, Ménétriés, Cat. Mus. Petrop. Lep. i. p. 85, pl. 2. fig. 2 (1855).

Two females. Kurrachee, June and July 1879.

"Very common in April, June, July, and August."

29. Terias asiope (No. 2).

Terias asiope, Ménétriés, Cat. Mus. Petrop. Lep. i. p. 85, pl. 2. fig. 3 (1855).

One male. Calcutta. "January, rare."

30. Terias leteta (No. 1).

Terias lata, Boisduval, Sp. Gén. Lép. i. p. 694 (1836).

One female. Belgaum.

Major Swinhoe says that $\boldsymbol{T}$. venata occurs rarely at Kurrachee in August.

\section{Teracolus vestalis.}

Teracolus vestalis, Butler, P. Z. S. 1876, p. 135. n. 32 , pl. 7. fig. 10.

Nine good specimens. Kurrachee, May 1879.

Major Swinhoe notes the following months in which this species may be taken-January to May, August, September, November, and December. This, however, is somewhat modified by subsequent remarks respecting this species and $T$. puellaris.

\section{Teracolus puellaris.}

Teracolus puellaris, Butler, P. Z. S. 1876, p. 136, n. 33 .

Ten specimens, mostly good. April and May, 1879.

Major Swinhoe says :- "The great distinction between the two above species, I take it, is the colouring of the underside, puellaris being yellow, and vestalis having a pinkish orange tinge, especially in the marginal border of the primaries and throughout the secondaries; but there appear to be two kinds distinct from vestalis, both of which I think are not puellaris, the black border on the upperside of the secondaries being twice as broad in the one as in the other; and as there are both sexes of each kind, I think they are distinct. I send you a series of 25 examples, 9 being the ordinary vestalis, 10 vestatis of a smaller size which are marked "Idmais No. 1" in my collection, and 6 marked " No. 2," which are like puellaris, except for the very narrow border on the secondaries; kindly tell me if these are puellaris or another species. I don't send you any more typical puellaris; you have plenty in the Museum collection, and they are rare here; and I have but four examples, one of these, by the way, being a monster, very darkly and strongly marked throughout with black, with many large dark spots on the underside of the secondaries," 
As there appears to be some little confusion respecting these white species of Teracolus, I may briefly diagnose them as follows :-

T. vestalis expands 20-24 lines; border of secondaries above broad in both sexes; wings below sulphur-yellow, the apex of primaries and entire surface of secondaries in the female occasionally irrorated with grey and washed with mustard-yellow, the secondaries also frequently with an oblique discal series of olive-brown spots. May.

T. puellaris expands 17-21 lines; border of secondaries above varying in width ${ }^{1}$; female often pale yellow above; male below usually of a brighter yellow than $T$. vestalis, and with narrower black discal spots; the apex of primaries and entire surface of secondaries in the female below flesh-coloured; the outer border of secondaries darker, and limited by a complete angular discal series of brownish spots. April and May.

T. ochreipennis expands 16 to $20 \frac{1}{2}$ lines; border of secondaries above rather broad in both sexes; both male and female white above in all specimens which I have seen; the apex of primaries and entire surface of secondaries in both sexes below ochraceous, the secondaries with rather darker border, limited internally by two or three brownish spots, which sometimes, however, are obsolete. November.

33. Teracolus ochreipennis (No. 2).

Teracolus ochreipennis, Butler, P. Z. S. p. 136. n. 34.(1876).

Six specimens, in tolerably good condition. Kurrachee, November 1879 .

\section{Teracolus dynamene.}

Pontia dynamene, Klug, Symb. Phys. pl. vi. figs. 17, 18 (1829).

Four specimens. Kurrachee, May 1879.

"Very common. May, November, December."-C. S.

Of T. protractus Major Swinhoe says :- "January, March, August, November, not common; very common in Hydrabad and on the Hubb river."

Of $T$. solaris (of which we only possess one specimen, a male) he says :- "January, August, December, common."

35. Teracolus etrida (No. 1).

Anthocharis etrida, Boisduval, Sp. Gén. Lép. i. p. 576 (1836).

Three typical males and one typical female. Kurrachee, May and June 1879.

Var. Orange apical patch wider in both sexes, its inner blackbrown boundary becoming obsolete towards the costal border in the male.

Three males and two females. Kurrachee, May and June 1879.

This variety resembles $T$. purus in the pattern of the apex of primaries.

1 Always narrow in Kurrachee males. 
36. Teracolus purus (Nos. $3 \& 4$ ).

Teracolus purus, Butler, P. Z. S. 1876, p. 160. n. 113, pl. 7. figs. $14,15$.

Four males and two females. Kurrachee, May and June 1879.

Four of the specimens, including the females, are labelled " 3 ;" the other two, males, are labelled " 4." The following species (if indeed it be distinct, which I begin to doubt) is similarly mixed up, one male and two females being labelled " 3 ," and two males " 4 ."

37. Teracolus bimbura (Nos. $3 \& 4$ ).

T'eracolus bimbura, Butler, P. Z. S. 1876, p. 161. n. 117, pl. 7. figs. 3,4 .

Three males and two females. Kurrachee, May 1879.

This form differs from $T$. purus in the narrower blackish borders to the apical orange patch in both sexes, the smaller marginal spots on the secondaries, the usually slightly inferior size; the difference of irroration on the under surface of the secondaries seems to be confined to specimens taken in Cashmere; but my figures of the upper surface accurately represent $T$. bimbura of Kurrachee. $\mathrm{My}$ figure of T.purus + doubtless represents the female of T. etrida, which, when I wrote my "Revision" of the genus, was a rare species in collections, and consequently not readily recognized by me. The true female of $\boldsymbol{T}$. purus is of about the same size as the male, and has a more curved orange patch on the apical area; the marginal spots on the secondaries are also rather smaller than in T. etrida 9 ; and the spots across the disk of these wings on the under surface are less conspicuous.

38. Teracolus dirus (Nos. $1 \& 2$ ).

T'eracolus dirus, Butler, P. Z. S. 1876, p. 157. n. 108, pl. 7. figs. $11 \& 13$, ㅇ․

One male and two females. Kurrachee, May and June, 1879.

This species is also said to occur in July and August. It is easily separable from $T$. dulcis by the much broader and darker grey patch at the base of all the wings, by the larger marginal black spots on the male, and the presence of an additional series of discal black spots on the disk of the secondaries on the female - a character wholly failing in Kurrachee females of $\boldsymbol{T}$. dulcis, and never represented elsewhere excepting by one or two indistinct spots: the under surface of the female secondaries also inclines to yellow in tint, whereas in $\boldsymbol{T}$. dulcis it is quite pink.

39. Teracolus dulcis (Nos. $1 \& 2$ ).

Teracolus dulcis, Butler, P. Z. S. 1876, p. 157. n. 107, pl. 7. fig. $130^{*}$.

Three males and two females. May and June 1879.

Major Swinhoe gives the following months for the appearance of this species :- "January, August, and November." It is possible, however, that he may have confounded it in life with the preceding 
species (as he has done in death), since it is hardly probable that the same species would be taken for eight months in succession. It is no wonder that any one, however much experienced in the study of the Lepidoptera generally, should confound the species of such difficult genera as Teracolus, Colias, and Terias; only special study can educate one readily to recognize the differences between many of them: doubtless a tendency to hybridization between allied species does not assist one in identifying them.

\section{Catopsilia thisorella.}

Callidryas thisorella, Boisduval, Sp. Gén. Lép. i. p. 609 (1836).

Two males. Kurrachee, May 1879.

Whether this race of $C$. pyranthe is constant to Kurrachee I have no means of judging. Major Swinhoe gives March, May, and December as its times of appearance, and says that it is common.

\section{Appias darada (No. 2).}

Pieris darada, Felder, Reise der Nov. Lep. p. 166, n. 142 $(186 \%)$.

One male. Neilgherries.

"One specimen, taken at Kurrachee; month not recorded.C. $S$.

\section{Appias narendra (No. 3 ).}

Appias narendra, Moore, Ann. \& Mag. Nat. Hist. ser. 4, vol. xx. p. 48 (1877).

One male. Neilgherries.

The female is at present unknown to us; but Major Swinhoe speaks of the probable female as "smaller, with broader marginal black band on the upper surface of the secondaries, and the under surface of these wings nearly white." It would be quite unusual for the female to be smaller than the male ; but this might be merely an individual character.

\section{Papilio mesentina.}

Papilio mesentina, Cramer, Pap. Exot. iii. pl. 270. f. A, B (1782).

A pair. Quetta, North Beloochistan, March 1880.

Occurs very commonly from February to May, and in November and December.

\section{SyNCHLOË DAPLIDICE.}

Papilio daplidice, Linnæus, Syst. Nat. (1) ii. p. 760 (1766).

A pair. Quetta, April 7th \& 15th, 1880.

45. Ganoris gliciria (No. 1).

Papilio gliciria, Cramer, Pap. Exot. ii. pl. 171. f. E, F (1779).

A pair. Neilgherries. 


\section{Ganoris manniI.}

Pontia mannii, Mayer, Stett. ent. Zeit. 1851, p. 151.

One specimen, Quetta, 26th March; two at Chaman, S. Afghanistan, in May 1880.

This looks much like a well-marked variety of the following species.

47. Ganoris Rape.

Papilio rapa, Linnæus, Faun. Suec. p. 270, n. 1936 (1761).

One specimen, Quetta, 26th March; one at Chaman, May 1880 .

48. Nepheronia pingasa (No. 1).

Eronia pingasa, Moore, P. Z. S. 1872, p. 365 .

One male. Neilgherries.

The specimen sent belongs to the variety in which the upper surface exactly resembles $N$. valeria $\delta$; and the under surface shows traces of the submarginal spots, which in the female limit the outer border. The species belongs to the $N$. valeria group, the females of which (unlike that of $N$. hippia) show no trace of yellow on the secondaries.

\section{Papilionine.}

49. Papilio buddha (No. 3).

Papilio buddha, Westwood, Trans. Ent. Soc. 1872, p. 86, pl. 3. fig. 1 .

One damaged specimen of this rare species. Neilgherries.

$P$. erithonius is said to be common at Kurrachee from January to March, August and December; and $P$. diphilus very common in August only.

\section{HESPERIIDE.}

50. Pamphila mathias.

Hesperia mathias, Fabricius, Ent. Syst. Suppl. p. 433 (1798).

One male. Kurrachee, June 1879.

"Very common in February, April, May, July, September, and November," according to Major Swinhoe; but it is probable that the following species is included in this statement.

\section{Pamphila karsana.}

Hesperia learsana, Moore, P.Z. S. 1874, p. 576, pl. 67. fig. 6 .

One male. Kurrachee, May 1879.

The small size, golden brown coloration, and absence of hyaline spots readily distinguish this from $\boldsymbol{P}$. mathias.

52. Pyrgus evanidus.

Pyrgus evanidus, Butler, Ann. \& Mag. Nat. Hist. ser, 5, vol. v. p. 223 .

Nine specimens. Kurrachee, 
The following times of appearance are given-January to March, June, August, and September ; but the following species was mixed up with the specimens of $P$. evanidus.

\section{Pyrgus galba.}

Hesperia galba, Fabricius, Ent. Syst. iii. (1) p. 352 (1793).

Eight specimens. Kurrachee.

The unbroken creamy white band across the centre of the secondaries on the under surface readily separates this species from the preceding, as also the straighter and continuous subbasal white line; as a rule, but not invariably, the under surface of $P$.galba is darker.

\section{HETEROCERA.}

SPHINGIDE.

\section{Cherocampa nessus (No. 1).}

Sphinx nessus, Drury, Ill. Exot. Ent. ii. p. 46, pl. 27. fig. 1 (1773).

One specimen. Belgaum.

"One specimen taken in October" (C.S.). Of other species found at Kurrachee are mentioned:-C. celerio, rarely in November and December; C. elpenor (probably C.fraterna), one specimen, probably taken in December, but the month not recorded at the time; and C. oldenlandia, one specimen in December; Deilephila livornica, one specimen taken in March.

\section{Pergesa acteus (No. 2).}

Sphinx acteus, Cramer, Pap. Exot. iii. pl. 248, A (1782).

One specimen. Belgaum.

The only other species of the family noted by Major Swinhoe are :Cephonodes hylas, one specimen of which was taken at Kurrachee in December; Daphnis nerii, taken from March to May; and Acherontia morta, which is common in July and August.

Respecting D. nerii, Major Swinhoe says :- "There appear to be three broods here, one after the other. I have taken caterpillars full-grown in all three months on the oleander which abounds everywhere in these parts : the caterpillars eat the flower only of the double garden oleander, and the leaves only of the wild single oleander. How this is I can't explain; but it is a fact I have carefully observed both in the jungles and the gardens here and when rearing them in my house. They are emerald-green at first, then turn dull yellow, and finally black before they leave off feeding; they burrow a few inches into the earth at the roots of the oleander, make a smooth cell, spin a very little silk, and the moth emerges in from 16 to 20 days. Out of 5 caterpillars in my breeding-cage, 3 became moths in 16 days after the chrysalis was formed and 2 in 20 days, there being one male in both instances." 
Agaristide.

56. Aggocera venulia (No. 40).

Phalcena venulia, Cramer, Pap. Exot. ii. pl. 165. f. D (1779).

One specimen. Neilgherries.

The Western form of this species differs from the Eastern in the greater length of the longitudinal white streak beyond the second black spot on the primaries.

\section{Arctione.}

57. Alon emittens (No. $2^{1}$ ).

Creatonotos emittens, Walker, Cat. Lep. Het. iii. p. 638 (1855).

One specimen. Belgaum.

Lithosinde.

58. Deiopeia thyter.

Deiopeia thyter, Butler, Trans. Ent. Soc. 1877, p. 361.

One specimen. Kurrachee, October 1879.

D. pulchella is said to be common in Kurrachee from January to March and in May and December.

\section{NyCtemerida.}

59. Nyctemera lacticinia (No. 42).

Phalana lacticinia, Cramer, Pap. Exot. ii. pl. 128. f. E (1779).

One specimen. Belgaum.

\section{Nycteolide.}

60. Earias tristrigosa, sp. n. (Nos. $20 \& 26$ ).

Nearly allied to $E$. frondosana, from which it chiefly differs in the absence of the brown border to the secondaries; primaries pea-green, with diffused whitish costal border, three darker green parallel angulated oblique stripes from the inner margin to near the costal margin, external border also darker green; secondaries semitransparent pearly white, slightly golden along the outer margin; thorax green; abdomen creamy yellowish. Primaries below pale greenish white, sericeous; secondaries as above, the costal border creamy; body below white. Expanse of wings $9 \frac{1}{2}$ to $10 \frac{1}{2}$ lines.

Two specimens. Hubb river, Beloochistan, February 1879; one (faded), Kurrachee, April 1879.

We have this species from the Punjanb.

\section{EnNomide.}

61. Hyperythra swinhoei.

Hyperythra swinhoei, Butler, Ann. \& Mag. Nat. Hist. ser. 5, vol.v. p. $223(1880)$.

Two males. Kurrachee, November 1879.

$$
1 \text { "Rhyparia No. } 2 \text { " (C. S.). }
$$


62. Hyperythra phantasma, sp. n. (No. 35).

Sordid creamy whitish or very pale stone-colour; wings sparsely speckled with grey and crossed by three equidistant olivaceous slightly arched lines, basal area to the second line slightly obscured, external area from the third line to the margin washed with olivaceous greenish; tegulæ and abdomen slightly darker than the rest of the body. Wings below cream-colour, the external area slightly darker and limited by a grey line rep resenting the third line of the upper surface; body brownish white. Expanse of wings 1 inch 6 lines.

One female. Kurrachee, February 1880.

Said to be rare. It is hardly likely to be the female of $H$. swinhoei, the latter being taken in November and having a more typical style of coloration with less regular lines across the wings. $H$. phantasma is an unusually colourless species, the under surface (which is usually far more brilliant than the upper surface) being almost uniformly creamy whitish.

\section{Geometride.}

\section{Loxоchila, gen. nov.}

Allied to Tunaorhinus and Geometra. From the former it differs in its more perfectly pectinated male antennæ, its shorter palpi, less falcate primaries, and in the second and third median branches of these wings being emitted at the same point from the inferior angle of the cell; from the latter in its shorter palpi, the shorter discoidal cell of the primaries, and the simultaneous emission of the median branches noted above; the male antennæ are scarcely so fully pectinated as in Geometra, as the apex remains bare. Type L. smaragdus (Tanaorhinus smaragdus, Butl.).

63. Loxochila mutans, sp. n. (No. 28).

Wings above pale sandy buff, probably dull sea-green when fresh (showing traces of this colour in some specimens), crossed in the middle from second third of costal margin of primaries to just beyond the middle of the abdominal margin of secondaries by a white line bordered internally by a line darker than the ground-colour; primaries with a second divergent transverse white line across the basal third; fringe of all the wings white: thorax of the same colour as the primaries; abdomen white; crest of head white; antennæ sandy yellowish. Under surface white, the costal borders of the wings, apical area of primaries, and a tint on the pectus and legs sandy buff, probably green in fresh specimens. Expanse of wings 1 inch $8-10$ lines.

One specimen. Neilgherries.

In addition to the example sent by Major Swinhoe (which shows no trace of the original green coloration), we have three specimens formerly in the collection of $\mathrm{Mr}$. Norris ${ }^{1}$, which show distinct

${ }^{1}$ Some of the species in this collection were described by Walker; and the types of the Indian forms were purchased by Mr. Moore. 
traces of green colouring similar to that of Thalera thymiaria of Europe. The only locality given is "N. India"! but there can be little doubt that they were all obtained in the Neilgherries; "N. India" seems to represent any thing, in some collections, from Scinde to Madras.

The genus Litbada of Walker appears to be allied to Loxochila and Geometra; but its brownish colouring seems to be permanent.

64. Nemorta pruinosa (No. 2).

Nemoria pruinosa, Butler, Ann. \& Mag. Nat. Hist. ser. 5, vol. v. p. 224. n. 19 (1880).

Two specimens. Kurrachee, September 1879.

"January, September, and December, not common."-C. S.

65. Nemoria frequens, sp. n. (No. 34).

Wings above sap-green, minutely reticulated with silvery white, fringe cream-coloured; palpi whitish, rose-red towards the tips; frons brown; crest and antennæ white; body above white; wings below silky white, slightly tinted with green towards the margins; body below silky cream-colour; front legs above slightly pink. Expanse of wings 11 lines.

One specimen. Kurrachee, March 1880.

Said to be common in April and November.

\section{Acidalinde.}

66. Acidalia distracta, sp. n. (No. 30).

Sandy whitish, densely irrorated with black, wings crossed in the middle by a very irregular dusky band formed by black scales on a testaceous ground, and having the appearance of two approximated lines; this band is almost divided (leaving only a slender line) upon the median interspaces of the primaries, and does not reach the costal margin of the secondaries; an indistinct dentate sinuate dusky discal line spotted upon the veins with black; a dusky undulated disco-submarginal band, interrupted in all the wings upon the radial and interno-median interspaces; a marginal black line interrupted at the extremities of all the veins; fringe white, speckled with black; primaries with an additional curved irterrupted dusky band across the basal third; a dusky discoidal stigma ; secondaries with a black discoidal stigma: under surface sericeous creamy white. Expanse of wings 1 inch.

Three specimens. Kurrachee, February 1879, May 1880. “January to March and May, common."-C. S.

\section{MACARIIDE.}

67. Macaria myandaria (No. 33).

Macaria myandaria, Walker, Cat. Lep. Het. xxvi. p. 1649 (1852).

One specimen, Matheran, May 1879. 
Fidonitde.

68. Sterrha sacraria (No. 31 ).

Phalcena sacraria, Linnæus, Syst. Nat. i. (2) p. 863 (1766).

One specimen. Kurrachee, September 1879.

Said to be taken rarely in November.

\section{LARENTIIDE.}

69. Larentia fissiferata, var. ? (No. 32).

Larentia fissiferata, Walker, Cat. Lep. Het. xxiv. p. 1194 (1862).

Two specimens. Neilgherries.

This species is allied to $L$. didymata of Europe.

70. Scotosia dubiosata (No. 29).

Scotosia dubiosata, Walker, Cat. Lép. Het. xxv. p. 1352 (1862).

One specimen. Neilgherries.

\section{LeUCANIIDE.}

71. Leucania loreyi (No. $1^{1}$ ).

Noctua loreyi, Duponchel, Hist. Nat. Lép. Fr.iv. p. 81, pl. 105. fig. 7 (1827).

One specimen. Kurrachee, April 1880. "February and April, rare."-C. $S$.

\section{XYLOPHASIIDE.}

72. Spodoptera cilium (No. 43).

Spodoptera cilium, Guénée, Noct. i. p. 154 (1852).

One specimen. Sajee, Southern Afghanistan, May 1880.

\section{Caradrinide.}

73. Amyna cephusalis (No. 46).

Ilattia cephusulis, Walker, Cat. Lep. Het. xvi. p. 209 (1858).

One specimen, Kurrachee, July 1880.

\section{Noctuide.}

74. Spelotis undulans? (No. 38).

Spalotis undulans, Moore, Sci. Res. Yark. Miss., Lep. pl. i. fig 10 (1879).

One specimen, Kurrachee, July 1880.

This example agrees in every respect with Moore's figure; the only cause for doubt is that the range seems somewhat extensive.

75. Chersotis quadrisigna (No. 6).

Agrotis quadrisigna, Moore, P. Z. S. 1881.

One broken example. Neilgherries.

This species is allied to C. rectangula of Europe.

$$
1 \text { "Prodenia No. } 1 \text { " on label. }
$$

Proc. Zool. Soc.-1881, No. XL. 


\section{Orthositide.}

76. Orthosia erubescens.

Orthosia erubescens, Butler, Ann. \& Mag. Nat. Hist. ser. 5, vol. v. p. 224 (1880).

One specimen. Neilgherries.

\section{HADENIDA.}

77. Hadena auriplena (No. 1 ').

Eurois? auriplena, Walker, Cat. Lep. Het. xi. p. 557 (1857).

One specimen. Neilgherries.

78. Anarta? gemmifera (No. $3^{2}$ ).

Plusia gemmifera, Walker, Cat. Lep. Het. xii. p. 934 (1857).

One specimen. Neilgherries.

This appears to me to agree far better with Anarta than with any other genus known to me.

\section{Anthophilide.}

79. Acantholipes affinis.

Docela affinis, Butler, Ann. \& Mag. Nat. Hist. ser. 5, vol. v. p. 225 (1880).

Three specimens. Kurrachee, April and May, 1880.

Also occurs in February, November, and December.

It will be seen by reference to my description that I called attention to the similarity of Docela to Microphysa (=Acantholipes), but stated at the same time that the palpi were longer and thicker. This I still think to be the case; but as Mr. Moore considers the two genera identical, I have no wish to retain Walker's appellation.

\section{Plusilde.}

80. Plusia verticillata (No. 1 ).

Plusia verticillata, Guénée, Noct. ii. p. 344 (1852).

Two specimens. Kurrachee, November 1879.

This species is said also to be common in February, March, and May. Major Swinhoe says he has a specimen in which the groundcolour is quite black, and another with a deep reddish tinge. He also mentions Abrostola subapicalis as taken at Kurrachee in November, and Xanthiodes intersepta as common in October and November.

\section{HOMOPTERIDE.}

81. Homoptera vetusta (No. 36 ).

Polydesma vetusta, Walker, Cat. Lep. Het. Suppl. iii. p. 875 (1865).

One specimen. Kurrachee, May 1880. 


\section{HYPogrammide.}

82. Rhizogramma inextricata (No. $1^{1}$ ).

Rhizogramma inextricata, Moore, P. Z. S. 1881, p. 342.

One example. Neilgherries.

This insect seems to me to come nearest to the genus Gadirtha.

83. Selepa docilis, sp. n. (No. 21).

Primaries above silver-grey, the basal area irregularly spotted with blackish and limited by two irregularly dentate-sinuatefarched parallel blackish lines; a black dot with white margin at the end of the cell, followed by two arched parallel blackish lines, which form an inangulated elbow at the first median branch; beyond these lines is an arched series of abbreviated longitudinal black dashes, followed by an alternated marginal series of similar dashes; a marginal black spot at the extremity of the first median branch : secondaries silvery white with slight golden reflections : thorax grey ; abdomen white. Wings below silvery white, the secondaries with pearly reflections; body below white. Expanse of wings 10 lines.

Var. Markings of primaries obsolete, with the exception of the outer discal line; the submarginal black dashes replaced by a slightly irregular greyish testaceous stripe. Expanse of wings $9 \frac{1}{2}$ lines.

Two specimens. Kurrachee, May 1879.

Also said to be common in November and December.

I am rather uncertain about the right position of the genus Selepa ; but its palpi are rather similar to those of Gadirtha; it also seems nearly allied to Egelesta, Plotheia, and Girbatha of Walker. The type species was, I believe, inadvertently referred by its author to the Limacodidæ; but from this family the structure of the body at once distinguishes it.

\section{OpHIDERIDA.}

84. Ophideres hypermnestra (No. 2).

Phalana hypermnestra, Cramer, Pap. Exot. iv. pl. 323. f. A, B (1782).

Two specimens. Belgaum.

OMMATOPHORIDE.

85. Argiva hieroglyphica, var. ulula (No. 1). Noctua ulula, Fabricius, Sp. Ins. ii. p. 211 (1781).

One specimen. Belgaum.

\section{Thria fugitiva.}

\section{Ophiuside.}

Cerbia fugitiva, Walker, Cat. Lep. Het. xiv. p. 1365 (1857).

One specimen. Kurrachee, May 1879.

The genus Cerbia must sink as a synonym of Thria, established at $p$. iv of the same volume; indeed I am doubtful whether even

${ }^{1}$ Labelled as a Cucullia, which it resembles except in its long palpi. 
the species is not identical with $T$. robusta. As, however, the latter comes from South Africa, and is less heavily marked and paler than the Indian specimens in the collection of the British Museum, I hesitate to regard the two forms as conspecific.

87. Thria? inepta, sp. n. (No. 44).

Primaries above with the basal three fifths sordid white, crossed near the base, and again at basal third, by irregular testaceous bands, the inner one with black internal and brown external margin, the outer one with brown internal and black external margin; a black costal dash between these bands; an oblique brownish patch, bisinuated in front, from the costa across the end of the cell, and beyond this a black costal dot; external three fifths greyish white, limited internally by a biangulated testaceous band having a black internal and brown external margin ; disk crossed by a broadly dentate sinuate white line with testaceous outer border, and with its sinuations (on the inside) filled in with brown; a dark brown apical spot; a slender marginal blackish line, dotted with black between the veins; fringe white, sordid externally, and traversed by a dusky sinuated line: secondaries white, with brownish abdominal area; median vein to the commencement of the branches and the external two fifths of the wing black-brown; an oblique marginal spot near the anal angle and the fringe white: body above sordid white. Wings below white: primaries crossed from the inner margin beyond the middle almost to the costa by two divergent brown bands, the outer one diffused, emitting longitudinal streaks outwards along the veins and joining a large black costal spot; a black spot at apex ; fringe brownish at the tips: secondaries with brown external area as above, but slightly paler, a large black spot at about the middle of the margin, bounded inwardly by the subanal marginal white spot: body below white, venter creamy. Expanse of wings 1 inch 7 lines.

One broken example, Chaman, Southern Afghanistan, May 1880.

\section{EUCLIDIIDA.}

\section{TRIgONODES HYPPASIA.}

Phalcena hyppasia, Cramer, Pap. Exot. iii. pl. 250. f. E (1782).

Three specimens. Kurrachee, July and October, 1879. Also said to be common in January, June, and September.

\section{REMIGIIDE.}

89. Girpa optatura (No. $2^{1}$ ).

Remigia opatura, Walker, Cat. Lep. Het. xv. p. 1848 (1858).

One specimen. Neilgherries.

\section{HERMINIIDE.}

90. Rivula sericealis (No. 24).

Pyralis sericealis, Denis, Wien. Verz. p. 122, n. 18.

Five specimens. Kurrachee, May 1879. 
"Very common in February, March, May, July, August, September, and November."- $C . S$.

\section{Pyralide.}

\section{Stemmatophora ingrata, $\mathrm{sp} . \mathrm{n}$.}

Primaries above whity brown; two white-bordered black dots placed transversely above one another at basal fourth; an irregularly falciform line beginning at about the middle of the inner margin, running obliquely upwards to the median vein, and then abruptly elbowed and sweeping outwards in a semicircle to the costal margin at apical sixth, white with brown internal border; secondaries white, apical border brownish ; thorax whity brown, abdomen white: under surface pure silky white. Expanse of wings $6 \frac{1}{2}$ lines.

Two rubbed specimens. Kurrachee, May 1880.

\section{Hypotia vulgaris, sp. n. (No. 17).}

Greyish brown: primaries above with a large patch of whity brown occupying nearly the whole of the basal third, which is limited externally by a dusky-bordered zigzag white stripe ; a white spot, bounded on each side by a blackish dot, within the end of the cell ; a dusky-bordered white zigzag band immediately beyond the cell, varied with pale buff or whity brown, speckled with grey, and diffused above the second median branch; a submarginal whitish dash across the third median and lower radial interspaces, and an oblique costal white dash close to apex; a marginal series of whiteedged blackish points ; fringe alternately greyish brown and white; in some specimens nearly the whole surface of the primaries is pale buff, only the area between the white bands being streaked or clouded with greyish brown, the inner white stripe or band being less zigzag, the marginal line-wholly white, and the fringe spotted at the base with blackish (this would seem to be the more typical male form) : secondaries sericeous, with diffused dusky border, usually with a submarginal series of white spots; fringe sordid white at base, pure white at tips, and traversed by two grey lines: thorax whitish. Under surface pale greyish brown; wings slightly darker towards the outer margin, and with an indistinct subapical whitish streak; a scarcely perceptible slender whitish marginal line ; fringe as above ; internal area of primaries whitish. Expanse of wings 9-12 lines.

Five specimens. Kurrachee, December 1879 and April 1880.

Also common in May, August, and November.

\section{ENNYCHID兵.}

\section{Rhodaria ARIDA, sp. n.}

Primaries above sandy buff, with reddish costal margin spotted with blackish ; central third occupied by a broad greyish belt with pale buff borders; a greyish diffused submarginal stripe; fringe grey, whitish at the base and traversed by a darker grey line: secondaries greyish brown, with fringe as in primaries: thorax testaceous; abdomen greyish brown. Under surface sericeous whity brown; pri- 
maries with yellowish costal border; a sandy whitish discal stripe, answering to the outer border of the central band on the upper surface; palpi ochreous. Expanse of wings 6 lines.

Five specimens. Kurrachee, May 1880.

The specimens of this species were unfortunately sent loose in a pillbox with several other small Lepidoptera, so that only one of the five examples is in fair condition, the others being a good deal rubbed.

\section{STENIIDE.}

94. Diasemia (?) geometralis (No. 22).

Lepyrodes geometralis, Guénée, Delt. et Pyral, p. 278 (1854).

Two specimens. Kurrachee, February 1879.

" Rare in December."- $C$. S.

\section{SPILOMELIDA.}

95. Zebronia aUrolinealis (No. 45).

Zebronia aurolinealis, Walker, Cat. Lep. Het. xvii. p. 478 (1859). Two specimens. Kurrachee, July 1880.

\section{Margarodidæ.}

96. Glyphodes univocalis (No. 47).

Glyphodes univocalis, Walker, Cat. Lep. Het. xvii. p. 499 (1859).

Six specimens and a fragment. Kurrachee, July 1880.

These specimens were sent in a pill-box, and have all suffered more or less in transit. It is a rare species in collections, and would be worth sending in good condition.

\section{BоTIDIDE.}

97. Godara incomalis (Nos. $23 \& 27$ ).

Pionea incomalis, Guénée, Delt. et Pyral. p. 369 (1854).

Four much-worn specimens. Kurrachee, May and December 1879.

According to Major Swinhoe this is a rare species; it also occurs in January.

\section{SCOPARIIDE.}

98. STENOPTERYX HYBRIDALIS (No. 25).

Pyralis hybridalis, Hübner, Pyral. pl. 17. fig. 114.

One specimen of this widely distributed species. Kurrachee, January 1880.

\section{Hellula undalis.}

Phalcena undalis, Fabricius, Ent. Syst. iii. (2) p. 226 (1793).

One specimen of this European species. Kurrachee, May 1880.

Scotomera, gen. nov.

Allied to Scoparia, but differing in its more triangular primaries, the veins of which are all well separated and considerably less 
parallel ; secondaries decidedly smaller, the costal vein and the subcostal branches well separated throughout their entire length, the inferior angle of the cell more produced; body more slender; palpi obliquely depressed.

100. Scotomera tristis, sp. n. (No. 18).

Primaries above blackish grey, an indistinct angulated stripe across the basal fourth and a second near the outer margin whitish, costa regularly dotted with whitish; secondaries pale grey with slight brownish reflections; head creamy white; thorax dark grey; abdomen pale grey : under surface silvery whitish; primaries with black-spotted costal margin; legs whity brown, mottled above with grey but very indistinctly. Expanse of wings 7 lines.

Two specimens. Kurrachee, April 1880.

\section{Phycide.}

\section{Mella zinckenella ${ }^{1}$ (No. 19 ).}

Phycis zinckenella, Treitschke, Schmett. Eur. ix. i. p. 201 (1832).

Phycis etiella, Treitschke, loc. cit. x. 3, p. 276 (1835).

Mella dymnusalis, Walker, Cat. Lep. Het. xix. p. 1018 (1859).

Assara albicostalis, Walker, loc. cit. xxvii. p. 80 (1863).

Modiana scitivittalis, Walker, loc. cit. p. 83 (1863).

Alata anticalis, Walker, loc. cit. p. 108 (1863).

Arucha indicatalis, Walker, loc. cit. p. 202 (1863).

Alata subaurella, Walker, loc. cit. xxxv. p. 1724 (1866).

Alata hastiferella, Walker, loc. cit. p. 1725 (1866).

Var. Etiella decipiens, Staudinger, Berl. ent. Zeit. p. 195 (1870).

Crambus sabulinus, Butler, Ann. \& Mag. Nat. Hist. ser. 5, vol. iv. p. 455 (1879).

Five specimens. Kurrachee, May and December 1879 .

Also common in March and November; the species seems to be perfectly cosmopolitan in its range.

\section{Tineide.}

\section{Tinea glabrella.}

Tinea glabrella, Walker, Cat. Lep. Het. xxviii. p. 478 (1863).

One specimen. Kurrachee, May 1880.

103. Hapsifera eburnea, sp. n. (No. 39).

Primaries pure snow-white, with the central longitudinal and external areas creamy white and speckled with brown, two or three darker brown spots in a longitudinal line below the cell, one across the end of the cell, and another halfway between the cell and the apex, a black spot at the origin of the first subcostal branch, and a marginal series of black dots; fringe with central and apical series

${ }_{1}^{1}$ The generic name Etiella being that of a synonym of the species, I have here adopted the first generic name given to the species by Walker. 
of black irrorations : secondaries silvery white with pearly reflections : body snow-white. Wings below sordid white with faint golden reflections; body white. Expanse of wings 10 lines.

One specimen. Kurrachee, July 1880.

\section{Eriocottis FUSCANELLA?}

Eriocottis fuscanella, Zeller, Isis, p. 813 (1847).

Two worn specimens. Kurrachee, May 1880.

The types and all the better examples in this series of Lepidoptera are incorporated with the national collection.

8. Note on some Points in the Anatomy of the Cæcum in the Rabbit (Lepus cuniculus) and Hare (Lepus timidus). By W. N. Parker, Assistant in the Biological Laboratory of the Royal School of Mines.

[Received March 15, 1881.]

(Plate LIII.)

Some few months ago Prof. Huxley called my attention to the fact that Krause's description of the relations of the ileum and sacculus rotundus to the cæeum in the Rabbit (Anatomie des Kaninchens, pp. 156, 157) was incorrect, and proposed that I should look the matter up. I therefore examined the structure of these parts again, not only in the Rabbit, but also in the Hare, and in doing so noted the following resemblances and differences.

In both the cæcum, as is usual in grass-eating mammals which have a comparatively simple stomach, is of a relatively enormous size, being on an average, when straightened out, about 1 foot 8 inches long in a moderate-sized Rabbit, and rather more in the Hare. This measurement includes the appendix vermiformis, which varies from about $3 \frac{1}{2}$ to $4 \frac{1}{2}$ inches in length.

The ileum appears externally, in both species, to pass directly into the sacculus rotundus, at right angles to the long axis of the cæcum. The sacculus has an ovoidal shape, its long axis being transverse to the long axis of the cæcum in the Rabbit (fig. Iv.), but longitudinal in the Hare (fig. II.)

In both also the cæcum passes insensibly into the colon, which runs straight from it for about 2 or $2 \frac{1}{4}$ inches, and then makes a sudden bend in the opposite direction, taking on the characteristic form, with the sacculations and the three tania coli.

Daubenton (Histoire Naturelle, tome sixième) describes the sacculus as a pocket near the junction of the ileum with the colon, and gives figures (pls. xl., xli. pp. 273, 274), of the Hare's cæcum both entire and cut open, the latter showing the two distinct apertures of the sacculus and ileum into the colon (fig. I. s.c, i.c); but he gives no details on this point in the Rabbit (p. 321). Krause describes these 


\section{$2 \mathrm{BHL}$ Biodiversity Heritage Library}

Butler, Arthur G. 1881. "On a Collection of Lepidoptera from Western India, Beloochistan, and Afghanistan." Proceedings of the Zoological Society of London 1881, 602-624. https://doi.org/10.1111/j.1096-3642.1881.tb01315.x.

View This Item Online: https://www.biodiversitylibrary.org/item/96698

DOI: https://doi.org/10.1111/j.1096-3642.1881.tb01315.x

Permalink: https://www.biodiversitylibrary.org/partpdf/73304

\section{Holding Institution}

Natural History Museum Library, London

\section{Sponsored by}

Natural History Museum Library, London

\section{Copyright \& Reuse}

Copyright Status: Public domain. The BHL considers that this work is no longer under copyright protection.

This document was created from content at the Biodiversity Heritage Library, the world's largest open access digital library for biodiversity literature and archives. Visit BHL at https://www.biodiversitylibrary.org. 